\title{
Objectivity is an Elusive Ideal that Can Never be Achieved
}

\author{
Mazen Ajjan \\ PhD Researcher \\ Federal Studies Dept., \\ Hamdard University, \\ New Delhi, India
}

DOI: https://doi.org/10.36941/mjss-2021-0o18

\begin{abstract}
The Paper investigates objectivity of Mass Media in the Middle East. The researcher chooses the most prominient news channel in that turbulent area of the world, namely Al-Jazeera Arabic news channel and examines its journey to claim its assumed objectivity. The paper gives analysis of objectivity in different cultureal contexts. It shows the ways Al-Jazeera established itself as an objective voice and how it presented itself as an alternative view to the dominant western perspective of global news. At the end the paper takes an intersting turn by bringing objectivity back to its "stallwart" - American journalism, where it was openly dropped in the face of national threat. The study realizes that the same conditions which gave Al-Jazeera Arabic its objectivity, in the eyes of its viewers, were the ones that its competitors used to disclaim its objectivity. Conditions can easily change if circumstances or attitudes changed. The paper concludes that Objectivity, in its bright side, is an elusive ideal that can never be achieved in our turbulant world.
\end{abstract}

Keywords: Middle East, Al-Jazeera, Objectivity, American journalism

\section{Introduction}

The story is told in Saudi Arabia of an American oil-company geologist, crossing a barren expanse of desert in 1969, well before the oil boom and dramatic Arab economic growth, who encountered a lone Bedouin tending his flock of camels and stopped to try out his own Arabic. When the Bedouin asked where he had come from, the American solemnly pointed to the sky and said, 'I have just come from the moon'. Without hesitation, the Bedouin replied, 'Oh, then you must be Neil Armstrong'. (Rugh, 2004)

This story may be apocryphal. However, if the details of the first lunar landing were quite known even in the remotest areas of the globe in 1969, it follows naturally then that hardly anyone, nowadays, is kept isolated from what is going on around them. Many ordninary individuals have even become fierce critics to events taking place in different parts of the world. Those ordinary individuals have started to have the ability to figure out the truth, evaluate media objectivity and to question their credibility.

The journalist in return, has become keen on seeking his/her own objectivity, since it is a 'cloak and a goal for a journalist to be fair (Reeves,1997:40). Good journalists would seek objectivity in their stories if they 'care about the truth' and because 'objectivity is a cornerstone of the professional 
ideology of journalists in liberal democracies (Lichtenberg 2000: 239)'.

The most basic definition to objectivity, therefore, is the ability to present facts uncoloured by feelings, opinions or personal bias. Even Lichtenberg adapted a notion that the safest way to be objective is to look neutral' (Lichtenberg 2000:252).

This definition sounds perfect in theory. In practice, however, there is always this question about mass media bias. The simpliest example that could affect journalistic objectivity, as Tuchman (1972) expresses it, is the publisher's pressure to have the story being published on the daily journal on time which forces the journalist to hand in his piece without investgating it properly. A example of that is an article in $\mathrm{Al}$ Sharq $\mathrm{Al}$ Awsat newspaper (18 April 2003) during Iraqi war.

'In the wake of the recent Iraq war, several Arab media outlets claimed that most of them began the war coverage with an objective angle but soon followed the sensational wave of the satellite channels in an attempt to attract larger audience'. (Hahn,2007)

In the Middle East, there is always that claim about unnutrality of the western mass media especially in relation to political affairs. The opposite is also true as Arab mass media is often accused by western media of lacking in objectivity.

In order to be specific in examining objectivity, this essay aims to look at objectivity in practice. It is going to examine the performance of an Arabic news channel; namely Al-Jazeera, during a threeyears period between (2003-2006) and compare it with its competetors locally and internationally. During this specified period of time, the whole world witnessed the American 'invasion' or 'liberation' to Iraq, the rises of 'freedom fighters' or 'terrorists' and the daily news of 'martyrs' or 'suiciders'. Also, in (2006) there was the Israeli war against "Hezbullah" or "the Lebanese resistence".

\section{Why Al-Jazeera}

According to Lynch (2006) the new Arab media arguably represented the single greatest strategic difference between 1991 and 2003. Al-Jazeera within less than two years from its launch in 1996 became a unique Arabic channel that ended the CNN era in Middle East which started by the 1991 war. Al-Jazeera began its own era in 1998 when the USA and Britain bombed Iraq, and became a prominent news channel in the 2001 war in Afghanistan then in the 2003 war in Iraq.

'For the first time, many Arabs did not have to rely on the BBC, CNN or other outside news sources when a big story broke. They could instead find news presented from Arab perspective (Saeb, 2007)'

In June 2004, a survey by Zogby International found that despite new competition, Al-Jazeera remained the most watched Arab news source overall. Al-Arabiya came next, while LBC did well only in Lebanon. In other words, despite the repeated warnings of its impending loss of credibility or audience, Al-Jazeera remained the market leader even as the market grew increasingly competitive.

A September 2004 survey of Saudi television preferece found that $82 \%$ watched al-Jazeera regularly, followed by $75 \%$ who watched al-Arabiya. (survey, Arab Advisors Group, 2004). In late 2004, a survey by the Greater Cairo area found that $88.4 \%$ of households with satellite television watch Al-Jazeera, followed by Al-Arabiya 35.1\%, CNN 6.6\%, al-Hurra 4.6\% and BBC 3.1\% (Arab advisors Group, 2005).

Also, in late 2004 a survey in Jordan found $72 \%$ watched Al-Jazeera and 54\% Al-Arabiya and only $1.5 \%$ watched the American station Al-Hurra. So, why Al-Jazeera is the number one channel in the Arab world? This is what the next section turns to.

\section{Is Al-Jazeera's Popularity Attributed to Its Objectivity?}

Lynch (2006) claims that Al-Jazeera, Al-Arabiya, and other Arab satellite stations reporting live from Iraq conveyed a picture of the war dramatically different to the emanating from the coalition, a 
picture that emphasized civilian suffering and American setbacks rather than a bloodless and popular liberation.

It is easy to agree with Lynch's viewpoint since Arabic channels were not included as embedded journalist during 2003 war waiting data and instructions from the coalition forces.

Philip Saeb (2007:7) went further in understanding Al-Jazeera effect and its credibility:

'Rather than judging the news product they receive according to standard prescribed by outsiders, most of Al-Jazeera's viewers consider Credibility to be a news provider's most important attribute, and these viewers want news that is gathered independently for Arabs by Arabs and that sees events through their eyes'

During the 2006 war between Israel and Hezbollah, Al-Jazeera provided more extensive coverage than what was offered by other international channels. The graphic images of dead and wounded Lebanese civilians and the vast destruction in Lebanon infrastructure affected the region's politics by stoking Arab anger towards Israel and United States. The crucial fact is that Al-Jazeera's reports from Lebanon raised the anger towards Arab governments that were slow in supporting Hezbollah. The overall coverage helped push countries such as Saudi Arabia and Jordan closer to Hezbollah's cause (Khalil, 2006).

Indeed, the media in the Middle East has had the capacity, perhaps for the first time in the modern history, to cause a shift in political decision making. The remarkable change in the Saudi and the Jordanian attitude to the 2006 war was primarily attributed to Al-Jazeera reports which presented 'different pictures' from what national and/or international channels used to present.

Al-Jazeera slogan “Opinion \& Counter Openion” strongly existed during the Iraqi or the later Lebanese war. It provided a counter opinion against the hegemony of western mass media (Mellor 2007). That was exactly what the Arab street were longing for. As a result, Al-Jazeera's objectivity was unquestionable in the eyes of its viewers.

Al-Jazeera was very careful in choosing lexicon that is different from the common trend used in American and even some Arabic news. Such lexicon articulated the real mentality and the pulse of the streets. "Media in some Arab Countries refers to Palestinians killed by Israelis as "martyrs" while the Israelis are referred to as "aggressors". Still, one of the main reasons of Al-Jazeera "Objectivity" in the eyes on Arab viewers is its commitment to pan-Arab issues (Ayish 2002:149)'. This is what Ayish termed 'a compromised objectivity'.

In its journey to seek objectivity, Al-Jazeera adapted, through its talk shows and opinion polls, a revolutionary way in touching the heart and mind of Arabic streets, forcing them to take a stand and criticise their regimes.

As an introductory to his weekly talk show 'The Opposite Direction' on $5^{\text {th }}$ November 2002, Faisal Al-Qassem, a very prominent TV host at Al-Jazeera said 'Only two places in the world have not seen protests against the coming American invasion of Iraq... Israel and the Arab world!'. Surprisingly, Arab viewers never heard that statement, which was very harsh yet very true, on their local TV. Even Al-Jazeera's first runner up 'Al-Arabia' did not dare mentioning such statement or asking such implied questions and leave it to viewers to make their own judgement.

Another example of objectivity is the case of Mohammad Hassaein Haykal. 'In summer 2004, Mohammad Hassaein Haykal, the Arab world's most famous journalist, was summarily banned from the Egyptian media after discussing critically the prospects of Gamal Mubarak succeeding his father as president in a fledgling Egyptian satellite station namely "Dream". In response, Haykal signed a hit deal by hosting a program on Al-Jazeerea Arabic, where his ideas and comments immediately and affectedly reached more Egyptian than on that domestic local Egyptian station (Lynch, 2004).

Another example to present here is, also, a very common case in most countries in the Middle East. Al-Arabiya and Al-Jazeera covered heavely the 2004 terrorist attack at Taba, whereas Egyptian channels continued their programs in a normal way 'a play here, a video clip here... it was as if this thing wasn't happening in Egypt leaving its people completly ignorant of what was going on (Atia, 
2004).

What has been presented so far indicates that the national Arab news media's desire to control information, and their enability to present the opposite viewpoint gave the floor to Al-Jazeera to gain its assumed credibility. It is not Al-Jazeera's adherence to its objectivity that made it successful. It is, in fact, the media infrastructure in the Arab world. In other word, it is the nature of the Middle East that enabled Al-Jazeera to design its own objectivity which was widely welcomed in the Arab street.

On the other hand, Lichtenberg (2000:251) pointed out that one of the elements to reach objectivity is to find the 'truth on both sides - or neither'. Therefore, it is important for Al-Jazeera to mention and questions aspects related to the state of Qatar instead of questioning aspects related to other countries e.g. Egypt. Mellor (2005:69) critically raised this point and opined 'when the state of Qatar is the main financial patron of Al-Jazeera, it is still debatable whether the channel is really journalistically free when critics accuse it of ignoring Qatari internal affairs'.

Similarly Arranging a daring political talk show dealing with external rather than internal issues in the Arab world is a remarkable phenomenon. Fandy (2000) calls this phenomenon 'anywhere but here' referring to the fact if Egyptian want to know about Egypt, they are better off watching Al Jazeera, while a Qatari is better served by reading Arab newspapers from outside Qatar to keep informed of what is happening inside Qatar. Needless to mention, then, that the question of objectivity is on the table again.

Tuchman (1972) argued in his examination of objectivity that newsman fear future sales being jeopardized, every story entails dangers for news personnel. Ironically, the Al-Jazeera faces the same fear of newsman with Qatar government. The "objective journalist" in Al-Jazeera can not cross some well defined red lines in relation to Qatar internal policy. The most apparent red lines in this regards are: 1-The Royal family affairs. 2- The American heavy military existance in Qatar.

Similar to what Fandy descibed above, the Arab viewers could open any other satellite channel to watch a thorough discussion on the two topics above.

\section{Al-Jazeera through the Western Eye}

Contrary to Al-Jazeera supporters in Middle East, who pertain that it represents the free voice for challenging the repressive Arab status and for defending Arab interests; many Americans view AlJazeera and the new Arab media as a fundamentally hostile force generating anti-Americanism and complicating foreign policy objectives in Iraq, Israel, and the war on terrorism (Lech, 2006). To its critics, Al-Jazeera represents a tremendously damaging cultural phenomenon, one which threatens to drag the struggling Arab world down into the abyss (Lech, 2006).

The Journalist Fadhil Fudha lamented that Al-Jazeera is transforming itself from an objective news station into a self-proclaimed carrier of an ideological message (Fudha, 2004). Furthermore, Mamoun Fandy who is a columnist for two daily newspapers Asharq al-Awsat in London and alAhram in Cairo and a senior fellow at the United States Institute of Peace, denounces the Arab media for succumbing to sensationalism and a "political pornography" (Fandy, 2003 sited in Lynch, 2006). He accused Al-Jazeera of adopting some expressions frequently used by Osama Ben Laden such as "Jazeerat al-Arab" (the Arabian Peninsula, a reference used in Arabic before the formation of the current Saudi state; as if the state never existed).

Such accusations; a mouthpiece to Osama Ben Laden or Qatar government, are enough to ruin Al-Jazeera image of objectivity.

Moreover, according to some American journalists, Al-Jazeera has become the most powerful ally of terror in the world even more important than Saudi financiers. We're foolish if we do not recongnize it as such. (Peters, 2004)

In congressional testimony, Martin Indyk, a leading Middle East policy maker under Bill Clinton, claims that Al-Jazeera may have given voice to a broad range of opinions but most of them were extreme in their anti-American and anti-Semitic sentiments. He reached a conclusion that it is useless trying to win the heart and mind of the Arab world because Arab leaders find it too useful to 
defect hostility outwardly (Lynch, 2006:20)'.

\section{Relativity of Objectivity}

The huge storm against Al-Jazeera objectivity (Saeb, 2007) points out that critics of Al-Jazeera, particularily in the West often challenge the channel's objectivity. Such criticism misses the point in terms of understanding the channel's baseline strength.

However, if the west missed the baseline strength, Saudi Arabia understood it well and for this main reason:

In February 2003, with \$300 million in start-up money from Saudi Arabia, technologically advanced facilities, and a veteran team of broadcasters, al-Arabiya set out to offer a more moderate alternative to al-Jazeera... Al-Arabiya set out to avoid using terms such as "martyrdom" or "resistance" instead adopting the "neutral vocabulary preferred by American critics of the Arab media. (Lynch, 2006:43)

The new channel was meant to be a mediator between westen and easten media. It will not discuss problematic issues in Iraq and will not give a voice to fundamentalist.

When President George W. Bush choose to grant interviews to Arab media to contain the damage of the Abu Ghraib scandals, he chose al-Arabiya (along with the American station Al-Hurra) as the outlet (Lynch, 2006:44). However, this proved no good for Al-Arabiya in terms of objectivity since the Arabic audience considered it as a mouthpiece to American propaganda in the region. Thus, Al-Arabiya gained some credibility from the west; however, it lost most of its credibility in the Arabic street.

The irony is that the same Arabic audience who criticised Al-Arabia did not consider Al-Jazeera a mouthpiece to Al-Qayda despite the fact that it was the only voice to Osama Bin Laden and other Qayda leaders and various field operations or hostage videos. This, again, could be attributed to the "nature of the viewers in Middle East" (Saeb, 2007) and the turbulant situation in the Middle East in general. By all means, however, it is not a positive mark for claiming objectivity.

\section{USA \& Objectivity: The Crises of Definition}

If, after all, a dead end is reached in search for objectivity in the Middle East then why not try finding it in another context. The United States and the 'nature of its viewers' could set a different horizon in our search for objectivity.

Hafez (2002) examined journalistic ethics in western and Arab countries, and confirmed that truth and objectivity are indeed among the universal media ethics as stressed in the respective ethical codes. If there is such a thing called 'universal media ethics', why there is not a one single working definition for objectivity? Why objectivity is difficult to attain?

Evensen (2002:264) answered these questions. During the second half of the twentieth century, American news media argued that the idea of objectivity versus interpretive reporting. Therefore, objectivity has been deemed "impossible" to attain. (Evensen cited in Mellor 2005:87).

Schudson (2003:187) defined three conditions that may jeopardize American journalism objectivity. These are 'tragedy, public danger, and threats to national security'. According to Schudson, objectivity is vulnerable to external circumstances. An example of this are journalists' reactions to the $9 / 11$ terrorist attacks. The three conditions were present at once when journalists assumed that 'there are no side' to take (Schudson, 2003:188). Tim Russert from MSNBC said 'Yes, I am a journalist, but first, I'm an American. Our country is at war with terrorists, and as an American, I support that effort wholeheartedly (El-Nawawy\&Iskander, 2002:4)'. CNN famous reporter Christiane Amanpour called for re-evaluation of objectivity, to make it "go hand in hand with morality" (Mindich 1998:4 cited in Mellor 2005:89). Ironically, CNN was the first American news channel that Donald Trump severely criticized immediately after his win in the presidential elections 2017 when he 
intentionally neglected a question from its correspondent Jim Acosta considering " $\mathrm{CNN}$ is giving fake news" (Time, 2017). Then insisted on his statement in 2019 (Fox News, 2019).

What is mentioned above is no good news for objectivity seekers since tragedy, public danger, threat to national security and terrorist attacts can exist anywhere and any time. If September 11 created this shift in tackling objectivity in democratic institutions in the USA, a legitamite question would be 'what would be the case then in the disturbant Middle East?' If objectivity is vulnerable in places of crises, why to reject objectivity that come from The Middle East? Moreover, if war coverage in the Arab media has been characterised as controversial (Mellor, 2005) simply because it adopted a perspective that is starkly different than that of the American media, could not American media be considered controversial as it adopts a different perspective to the Arab media? Coverage in American media which Mellor mentioned could be also controversial similar to Arab media.

The core point is that news cannot reflect the reality in a neutral viewpoint. As Schudson put it 'News is not a mirror of reality. It is representation of the world, and all representations are selective' (2003:33). In other word, each journalist can claim his/her own objectivity.

Objectivity even in USA and any democratic institution is related to certain conditions and obligations that may change with the change of circumstances. Ironically, $11^{\text {th }}$ September brought these changes a step closer to push objectivity a step further. It is no longer the "Middle East nature of viewer in the turbulant Middle East" as Saeb earlier put it, it is the nature of viewers in the whole turbulant world.

\section{Conclusion}

In this paper, I tried to investigate whether objectivity does exist in reality or whether it is nothing more than an elusive ideal. I tried to discuss it by focusing on one channel in a certain geographical area in a certain period of time, then looked at the feedback both from its viewers and competitors. I noticed that the same conditions which gave that channel its objectivity, in the eyes of its viewers, were the ones that its competitors used to disclaim its objectivity!

As a matter of fact, everyone knows that conditions can change easily and are subject to change if some circumstances or attitudes were changed. Objectivity, in its bright side can never be reached. In our turbulant world, in the East or in the West, circumstances can easily change and change their related objectivity in turn.

If we go back to the Bedouin in the far barren desert at the begining of our story, we can proudly say that 52 years ago he was well aquainted with the latest technical information. Sadly, in our revolutionary information age, there is no way for him or for anyone else on the globe, to get a real objective picture of any piece of information for objectivity is nothing but an elusive ideal.

\section{References}

Arab advisors Group. (2005, January 26).

Arab Advisory Groub. (2005, January). Retrieved October 7, 2020, from Al Bawaba.

http://www1.albawaba.com/en/business/survey-683-greater-cairo-tv-viewers-tune-news-channels

Atia, T. (2004, October 14). Aiming for Extinction. Al-Ahram Weekly .

Fandy, M. (2003, March 30). Perceptions: Where al_ Jazeera and Co. Are coming from. Washington Post .

Fox, CNN fake News, 2019 https://www.youtube.com/watch?v=s9m9ooS7RIY\&list=PLKPqJcw8D 5 OHoqQCEfjAXW7zDiGbYiDmC\&index=9o (Last retrieved 2-2-2021)

Fudha, F. (2004, May 5). Al-Jazeera and the Declining Arab Media. Elaph .

Group, A. A. (2004, September 10). survey,. Arab News .

Khalil, A. (2006). Major Arab News Channels Tested in Lebanon War. Agence France Presse.

Lynch, M. (2006). Voices of the New Arab Public. Columbia University Press.

Peters, r. (2004, June 21). New York Post .

Reeves, R. (1997). 'The Question of Media Bias ' In:Iyenger, Shanto \& Reeves, Richard, Do The Media Govern? Politicians, Voters, and Reporters in America,London (SAGE POublications. 
Mellor, N. (2005). The Making of Arab News. UK: Rowman \& Littlefield.

Mellor, N. (2007). Modern Arab Journalism. UK: Edinburgh University Press.

Lichtenberg, J. (200o). 'In Defence of Objectivity Revisited ' In:Curran, James \& Michael Gurevitch Mass media and Society, (3rd edition ed.). (J. \&. Curran, Ed.) London: Arnold.

Oliver Hahn. (2007). Arab Media and Political Renewal. London: I.B. Tauris\&Co. Ltd.

Philip Saeb. (2007). Mew media and the New Middle East. New York: Palgrave Macmillan.

Rugh, W. A. (2004). Arab Mass Media. Praeger Publishers.

Times, CNN fake news, 2017 https://www.youtube.com/watch?v=Yo3oxSS1Uyw\&list=PLKPqJcw8D5 OHoqQCEfjAXW7zDiGbYiDmC\&index=88 (Last retrieved 2-2-2021)

Tuchman, G. (1972). Objectivity as strategic Ritual. An Examination of Newsmen's Notions of Objectivity. American Journal of Sociology , 54, 422-443. 